\section{Studia \\ z Filologii Polskiej \\ i Słowiańskiej}

DOI: $10.11649 /$ sfps.2036
Studia z Filologii Polskiej i Słowiańskiej, 55

Warszawa 2020

Article No. 2036

Citation:

Jovanović-Mihaylov, V. (2020). Analiza kognitywno-semantyczna polskich oraz serbskich związków frazeologicznych z komponentem somatycznym określających stany emocjonalno-uczuciowe. Studia z Filologii Polskiej i Słowiańskiej, 55, Article 2036. https://doi.org/10.11649/sfps.2036

Vesna Jovanović-Mihaylov

(Uniwersytet Śląski w Katowicach)

\title{
Analiza kognitywno-semantyczna polskich oraz serbskich związków frazeologicznych z komponentem somatycznym określających stany emocjonalno-uczuciowe
}

\section{Wstęp}

Pomimo wzrastającej liczby publikacji naukowych w zakresie frazeologii kontrastywnej nadal brak jest opracowań w dziedzinie somatycznej frazeologii porównawczej pomiędzy językiem polskim a serbskim (zob. m.in. Gojković, 2013; Mušović, 2002). Z tej przyczyny przedmiot niniejszego artykułu stanowi analiza związków frazeologicznych wyrażających stany emocjonalno-uczuciowe uformowane wokół polskich oraz serbskich somatyzmów. Analizę przeprowadzono w ujęciu kognitywno-semantycznym. Podstawowy problem badawczy sprowadza się do następującego pytania: czy i jakie podobieństwa oraz różnice w zakresie badanego tematu występują między dwoma językami słowiańskimi wywodzącymi się z różnych podgrup językowych - polskim (podgrupa zachodniosłowiańska) oraz serbskim (południowosłowiańska)?

This is an Open Access article distributed under the terms of the Creative Commons Attribution 3.0 PL License (creativecommons.org/licenses/by/3.0/pl/), which permits redistribution, commercial and non-commercial, provided that the article is properly cited. (c) The Author(s) 2020.

Publisher: Institute of Slavic Studies, Polish Academy of Sciences

[Wydawca: Instytut Slawistyki Polskiej Akademii Nauk] 
W psychologii oraz naukach społecznych nie istnieje jasna definicja określająca zakres pojęcia „stany emocjonalno-uczuciowe”. Mówiąc o ludzkich stanach emocjonalnych, często używa się zamiennie terminów emocja i uczucie ${ }^{1}$. Znana jest powszechnie postawa rosyjskiego filozofa Iwana Pawłowa. Uczony ten uczucia powiązał z funkcją kory mózgowej, natomiast emocje - z pracą ośrodków podkorowych. Natomiast większość badaczy definiuje uczucie jako rodzaj emocji, który ma bardziej trwały charakter i nie ulega częstym zmianom. Przykładowo, Gerald C. Clore, Keith Oatley i Jennifer M. Jenkins oraz Joseph E. LeDoux posługują się zarówno terminem emocje, jak i uczucia (za: Łosiak, 2007). Z kolei Richard S. Lazarus i Klaus R. Scherer traktują uczucia jako składniki procesu emocjonalnego, uważając, że emocje występują nadrzędnie w stosunku do innych stanów człowieka, np. uczuć, nastrojów czy afektów (Łosiak, 2007). W niniejszym badaniu uczucia są uważane za jeden z rodzajów emocji, tym samym zostały potraktowane jako stany emocjonalno-uczuciowe.

W ciągu ostatnich kilku dziesięcioleci w przypadku badań frazeologicznych mamy do czynienia $\mathrm{z}$ wyraźnym powiązaniem zjawisk nie tylko językowych, lecz także kulturowych i kognitywnych. W centrum zainteresowania kognitywnej lingwistyki znajduje się język ściśle powiązany z umysłowymi procesami dotyczącymi postrzegania świata, a jednym $z$ jego głównych pojęć jest językowy obraz świata ${ }^{2}$. Kognitywiści, w przeciwieństwie do strukturalistów, są przedstawicielami językoznawstwa antropologicznego oraz kulturowego. Tego typu stwierdzenia są widoczne także w pracach polskich badaczy: Edwarda Łuczyńskiego i Jolanty Maćkiewicz. Oznacza to, że przedmiotem ich zainteresowania jest człowiek mówiący (homo loquens) i tym samym badają oni powiązania językowych zachowań z myśleniem użytkowników języka, ich naturą oraz kulturą (Łuczyński \& Maćkiewicz, 2009, s. 29).

Powstawaniu nowych związków frazeologicznych na gruncie polskim i serbskim często sprzyjały dwa procesy. Pierwszy z nich to proces metaforyzacji, czyli rozumienie i doświadczanie pewnego rodzaju rzeczy w kategoriach innej rzeczy. Drugi to proces metonimiczny, w którym liczne związki frazeologiczne powstały na drodze procesu prowadzącego do powstania metonimii. Warto przypomnieć, że według Georga Lakoffa i Marka Johnsona metafora oraz pojęcia metonimiczne są obecne w naszym życiu codziennym zarówno w języku, jak i w myślach, działaniu i mówieniu (Lakoff \& Johnson, 1988, s. 26). Za pomocą

1 Zob. więcej na ten temat: Spagińska-Pruszak, 2005b, ss. 36-38.

2 Zob. więcej na ten temat: Pajdzińska, 1990. 
tzw. metafor ontologicznych, których podstawą jest m.in. doświadczanie ciała ludzkiego, pojmujemy wydarzenia, działania, czynności, uczucia i stany. Wydarzenia i czynności traktujemy jako przedmioty; działania - jako substancje; uczucia i stany - jako pojemniki (Lakoff \& Johnson, 1988, s. 54).

Stany emocjonalno-uczuciowe można zinterpretować metajęzykowo za pomocą opisania ich objawów, w sposób metaforyczny czy też metonimiczny. Zrozumienie związków frazeologicznych wyrażających stany emocjonalno-uczuciowe wymaga wnikliwej analizy. Podejmując się tego zadania, należy sięgnąć do ich motywacji leksykalnej, jak i motywacji związków frazeologicznych, która jest uwarunkowana czynnikami pozajęzykowymi, czyli do motywacji - jak określił ją Andrzej Maria Lewicki - globalnej (Lewicki, 2003), a także do wspomnianych powyżej uwarunkowań kulturowych i antropologicznych.

\section{Analiza kognitywno-semantyczna}

W literaturze psychologicznej wielu badaczy proponuje rozmaite, różniące się między sobą schematy emocji podstawowych. W niniejszym badaniu posłużono się klasyfikacją podstawowych emocji W. Gerroda Parrotta, który podzielił je na 6 typów - miłość, radość, zaskoczenie, złość, smutek oraz strach (Gerrod Parrott, 2001). Do analizy wybrano po jednym typie emocji z klasyfikacji Gerroda Parrotta, które mają różne konotacje: od pozytywnych (miłość), poprzez neutralne (zaskoczenie), do negatywnych (złość). Tę klasyfikację dla potrzeb niniejszego artykułu zmodyfikowano, przydzielając do każdego $\mathrm{z}$ wydzielonych typów określone podtypy. W ten sposób powstały trzy grupy, których analiza pozwala dostrzec, czy pomiędzy realizacjami danej grupy emocji w obu językach słowiańskich występuje więcej podobieństw czy też różnic.

Poszczególne typy emocji wraz z podtypami przedstawiono w tab. 1.

Tabela 1. Podział emocji analizowanych w pracy

\begin{tabular}{|c|c|c|}
\hline Emocje pozytywne & Emocje neutralne & Emocje negatywne \\
\hline $\begin{array}{l}\text { Miłość - przyjaźń - przy- } \\
\text { wiązanie }\end{array}$ & $\begin{array}{l}\text { Zaskoczenie - zdziwie- } \\
\text { nie - zdumienie }\end{array}$ & $\begin{array}{l}\text { Złość - gniew - oburze- } \\
\text { nie - rozdrażnienie }\end{array}$ \\
\hline
\end{tabular}

Analizę przeprowadzono na podstawie korpusu wyekscerpowanego ze słowników frazeologicznych: Skorupki (Skorupka, 1987), Dobrowolskiej 
i Kawy (Dobrowolska \& Kawa, 2007), Matešicia (Matešić, 1982), Vujanicia (Vujanić, 2007), Otaševicia (Otašević, 2012) i Živanovicia (Živanović, 1999).

Do korpusu frazeologicznego włączono te frazeologizmy, które zawierają w swoim członie przynajmniej jeden somatyzm.

W korpusie uwzględniono te nazwy części ciała i ich synonimiczne odpowiedniki, które pozwalają wyodrębnić frazeologizmy określające stany emocjonalno-uczuciowe. Ponadto zamieszczono przede wszystkim te związki frazeologiczne, które mają wyższą frekwencję w środkach masowego przekazu. Do korpusu nie włączono przysłów, porzekadeł oraz takich związków frazeologicznych, które wyszły bądź wychodzą z użycia, czyli archaizmów, np. pol. wyżej nosa gębę nosić. Do korpusu zostały włączone frazeologizmy z języka literackiego, jak również te, które występują w odmianie mówionej miejskiej (potocznej).

Niniejsza analiza koncentruje się na znaczeniu poszczególnych frazeologizmów, a także informuje, w jakim stopniu symbolika danych części ciała wpłynęła na kształtowanie znaczenia frazeologicznego. Zwrócono także uwagę na wspomnianą wyżej motywację globalną. Przystępując do tego typu badania należy jednak pamiętać, że nie da się odczytać pełnej motywacji leżącej u podstaw wszystkich związków frazeologicznych, ponieważ po upływie długiego czasu, który minął od ich powstania, nie zawsze wiadomo, jakie sytuacje pozajęzykowe oraz wiedza o świecie legły u jej podstaw. Należy jednak spróbować odpowiedzieć na pytanie, za pomocą jakich ludzkich doświadczeń kształtował się obraz świata i tym samym tworzyło się dane znaczenie frazeologiczne $\mathrm{w}$ analizowanych językach słowiańskich. W tym celu pomocne okazały się obok ogólnych słowników współczesnych także Słownik symboli (Kopaliński, 1991), Słownik obrazów i symboli biblijnych (Lurker, 1989) oraz Encyklopedia popularna PWN (Encyklopedia popularna PWN, 1985).

\section{Emocje pozytywne}

Tabela 2. Miłość - przyjaźń - przywiązanie (język polski)

\begin{tabular}{|l|l|c|}
\hline GLOWA & $\begin{array}{l}\text { stracić / tracić głowę dla kogoś } \\
\text { zawrócić / zawracać komuś w głowie } \\
\text { stanąć / stawać dla kogoś na głowie }\end{array}$ & 3 \\
\hline JĘZYK & mieć (znajdować) z kimś wspólny język & 1 \\
\hline RAMIE & ramię w ramię & 1 \\
\hline RĘKA & nosić kogoś na rękach & 1 \\
\hline
\end{tabular}




\begin{tabular}{|l|l|r|}
\hline SERCE & $\begin{array}{l}\text { ofiarować (dać, oddać, poświęcić) komuś serce } \\
\text { odkryć (otworzyć) komuś (przed kimś) swoje serce } \\
\text { serce czyjeś bije dla kogoś } \\
\text { vosić (mieć) kogoś w sercu } \\
\text { z głębi serca } \\
\text { podbić / podbijać czyjeś serce } \\
\text { i iść za głosem serca }\end{array}$ & 7 \\
\hline STOPA & $\begin{array}{l}\text { żyć (być) z kimś na jakiejś (dobrej, poufałej, równej itp.) stopie } \\
\text { traktować kogoś na jakiejś (dobrej, poufałej, równej itp.) stopie }\end{array}$ & 2 \\
\hline SZYJA & rzucać się komuś na szyję & 1 \\
\hline UCHO & zakochać (zabujać) się w kimś po uszy & 1 \\
\hline Razem & & 17 \\
\hline
\end{tabular}

Tabela 3. Miłość - przyjaźń - przywiązanie (język serbski)

\begin{tabular}{|c|c|c|}
\hline BPAT & • бацити се (пасти, обесити се) око врата некоме & 1 \\
\hline ГЛАВА & $\begin{array}{l}\text { изгубити / губити главу за ким } \\
\text { завртети главу (главом) некоме } \\
\text { ж живети (бити) као глава и узглавље }\end{array}$ & 3 \\
\hline ДЛАН & • носити на длану некога, нешто & 1 \\
\hline ЈЕЗИК & • имати (наћи) с ким заједнички језик & 1 \\
\hline НОГА & • живети с ким на доброј (пријатељској) нози & 1 \\
\hline НОКАТ & • бити (живети, пазити се) с ким као нокат и месо & 1 \\
\hline ПРСТ & • бити с ким као прст и нокат & 1 \\
\hline PAME & $\diamond$ раме уз раме & 1 \\
\hline СРЦЕ & $\begin{array}{l}\text { поклонити (предати / предавати) (своје) срце некоме } \\
\text { открити (отворити / отварати) (своје) срце некоме } \\
\text { срце куца некоме за ким, за чим } \\
\text { носити (имати) у срцу некога, нешто } \\
\text { из (до) дубине срца (из дна срца) } \\
\text { освојити / освајати чије срце } \\
\end{array}$ & 6 \\
\hline УВО & • заљубити се до (преко) ушију & 1 \\
\hline \multicolumn{2}{|l|}{ Razem } & 17 \\
\hline
\end{tabular}

Grupa miłość - przyjaźń - przywiązanie zawiera 17 związków frazeologicznych w języku polskim oraz $17 \mathrm{w}$ języku serbskim.

W badanym korpusie obu języków przeważają związki frazeologiczne z komponentem serce / cpue. Oznacza to, że zarówno w kulturze polskiej, jak i serbskiej uczucia wiążą się przede wszystkim z sercem, które ma związek z życiem emocjonalnym człowieka i jest pojemnikiem, w którym mieszczą się uczucia. Można rozważyć na przykład zwroty: 
ofiarować komuś serce, odkryć komuś swoje serce, serce czyjeś bije dla kogoś, nosić kogoś w sercu.

W języku polskim tego typu zwroty przedstawiają serce jako symbol miłości czy też kierowania się w życiu miłością. Podobna sytuacja występuje we frazeologizmach w języku serbskim:

предати срие некоме,

открити срие некоме, носити у сриу некога.

Frazeologizmy wyrażają pozytywne uczucia i są motywowane metaforycznie.

Jak stwierdził Manfred Lurker (Lurker, 1989, s. 209), istota człowieka wyraża się nie w tym, co jest widoczne na zewnątrz, lecz w tym, co stanowi jego wnętrze. Tym samym serce stanowi centrum ludzkich emocji (Kopaliński, 1991, s. 371) i zajmuje centralne miejsce w wierzeniach wszystkich ludów (Lurker, 1989, s. 209). Przykładowo u starożytnych Egipcjan serce było ośrodkiem inteligencji, $\mathrm{w}$ tradycji muzułmańskiej jest ono $\mathrm{z}$ kolei postrzegane jako organ służący do kontemplacji i życia duchowego (Kopaliński, 1991, s. 371).

Głowa $\mathrm{z}$ kolei uważana jest za najważniejszy organ w ludzkim ciele. To siedlisko naszego intelektu, siły, odwagi, a także emocji. Stanowi swoisty pojemnik na myśli. Komponent głowa pojawia się w języku polskim i serbskim w następujących frazeologizmach:

pol. stracić głowę dla kogoś

serb. изгубити / губити главу за ким

ze znaczeniem 'zakochać się w kimś, nie widzieć świata poza kimś',

pol. zawrócić komuś w głowie

serb. завртети главу (главом) некоме

ze znaczeniem 'rozkochać / rozkochiwać kogoś w sobie, oczarować kogoś'. Zarówno w języku polskim, jak i serbskim zwroty z leksemem głowa odnoszą się do człowieka, który jest zdolny wiele zrobić i poświęcić dla miłości.

$\mathrm{W}$ badanych jednostkach istnieją również nieprzekładalne na drugi język tzw. związki stałe - związki idiomatyczne / idiomy. Jeden ze zwrotów jest idiomatyczny dla języka polskiego: stanać / stawać dla kogoś na głowie ze znaczeniem 'zrobić dla kogoś wszystko'. W omawianej grupie występuje także 
jeden frazeologizm idiomatyczny dla języka serbskiego i jest on motywowany metaforycznie: живети (бити) као глава и узглавле. Pokazuje obraz człowieka, który jest oddany drugiej osobie, okazując jej pozytywne, ciepłe uczucia.

W każdym z języków występuje jeden frazeologizm z komponentem język / jeзик. W języku polskim: mieć z kimś wspólny język, natomiast w serbskim: имати с ким заједнички језик. Język symbolizuje siłę przekonywania w miłości, przyjaźni, zbiór środków służących do wyrażania myśli i porozumiewania się między ludźmi (Kopaliński, 1991, s. 126).

Z komponentem ramię / paMe występuje w obu językach wyrażenie:

pol. ramię $w$ ramie

serb. paме уз раме

ze znaczeniem 'razem, solidarnie'. Wyrażenie to odnosi się do człowieka, który jest oddany drugiemu człowiekowi. Ramię w wymienionych frazeologizmach symbolizuje siłę, przywiązanie, oparcie w kimś.

Z komponentem szyja / вpam wyróżniamy po jednym zwrocie w obu językach. W języku polskim: zwrot rzucać się komuś na szyję może oznaczać dosłowne działanie, a frazeologizm jest wówczas motywowany ludzkim gestem, który polega na wykonywaniu gwałtownych ruchów w celu objęcia, przytulenia kogoś. Z kolei w znaczeniu metaforycznym przedstawia ofiarowanie miłości drugiemu człowiekowi, co wiąże się z pozytywnymi stanami emocjonalno-uczuciowymi. Takie samo znaczenie przypisane jest serbskiemu zwrotowi бацити се око врата некоме. Znaczenie jest także uwarunkowane socjalnie i ma motywację symboliczną. Tego typu frazeologizmy to przede wszystkim zwroty (tzw. predykaty frazeologiczne) uformowane na podstawie ludzkich zachowań i obserwacji (Lewicki, 2003, s. 285).

Komponent ucho / yвo występuje w zwrotach, które wyrażają głębokie uczucia w kierunku drugiego człowieka. W polskim zakochać się w kimś po uszy, w serbskim залубити се до (преко) ушију.

Należy wziąć pod uwagę, że przedstawiciele różnych kultur doświadczają podobnych emocji i uczuć, lecz nierzadko inaczej je kategoryzują. Zasób frazeologiczny języka polskiego posiada zwrot z komponentem ręka: nosić kogoś na rękach ze znaczeniem 'bardzo o kogoś dbać, troszczyć się; być dla kogoś bardzo dobrym', z kolei w języku serbskim występuje frazeologizm o tym samym znaczeniu, ale z komponentem dłoń: носити на длану некога, нешто. Dłoń definiuje się jako część ręki od nadgarstka po końce palców i często nazywa, rozszerzając potocznie jej znaczenie, ręką. Z kolei w Encyklopedii popularnej $P W N$ możemy spotkać odmienną definicję - dłoń jest definiowana jako 
wewnętrzna powierzchnia ręki człowieka i małp, pokryta liniami papilarnymi i nie jest ona uważana za część ciała (Encyklopedia popularna PWN, 1985, s. 165).

Za pomocą komponentów npcm (pol.palec) i нокam (pol. paznokieć) w języku serbskim pokazany jest obraz człowieka oddanego drugiemu człowiekowi:

бити с ким као прст и нокат

бити (живети, пазити се) с ким као нокат и месо.

Jak wiadomo, ruchy palców (i rąk) były i są u wszystkich ludzi pomocne w wyrażaniu myśli i uczuć. Powyższe zwroty powstały na drodze metonimii. Palec i paznokieć są częścią ręki. Ręka z kolei symbolizuje przyjaźń, czyli człowieka, który jest (żyje) w dobrych stosunkach / w przyjaźni z drugim człowiekiem.

Komponent stopa użyty w zwrotach: $\dot{z} y c ́$ (być) z kimś / traktować kogoś na jakiejś (dobrej, poufałej, równej itp.) stopie ze znaczeniem 'być z kimś w jakichś (dobrych itp.) stosunkach; traktować kogoś dobrze itp.'. Z kolei w języku serbskim istnieje zwrot o tym samym znaczeniu, ale z komponentem нога: живети (бити) с ким на доброј (пријательској) нози. Pokazuje to drogę motywacji wymienionych frazeologizmów. Stopa jest częścią nogi, co oznacza, że mamy do czynienia z odmianą metonimii - synekdochą.

\section{Emocje neutralne}

Tabela 4. Zaskoczenie - zdziwienie - zdumienie (język polski)

\begin{tabular}{|c|c|c|}
\hline CZOŁO & • puknąć się (stuknąć się, uderzyć się) w czoło & 1 \\
\hline GŁOWA & $\begin{array}{l}\text { złapać się / łapać się (brać się, chwytać się, wziąć się) za głowę } \\
\text { - kręcić głową } \\
\text { • kręci się komuś w głowie } \\
\text { jak bez głowy (chodzić bez głowy) } \\
\text { podrapać się / drapać się po głowie } \\
\text { pachodzić w głowę }\end{array}$ & 6 \\
\hline OKO & $\begin{array}{l}\text { wybałuszyć (wytrzeszczyć) oczy } \\
\text { zrobić / robić wielkie (duże) oczy } \\
\text { oko zbieleje (zbielało) komuś } \\
\text { nie wierzyć (nie dowierzać) własnym (swoim) oczom } \\
\text { patrzeć na kogoś, na coś osłupiałymi oczyma } \\
\text { postawić / stawiać oczy w słup }\end{array}$ & 6 \\
\hline RAMIE & $\diamond$ wzruszyć / wzruszać ramionami & 1 \\
\hline $\mathrm{UCHO}$ & • nie wierzyć własnym uszom (uszom nie wierzyć) & 1 \\
\hline \multicolumn{2}{|l|}{ Razem } & 15 \\
\hline
\end{tabular}


Tabela 5. Zaskoczenie - zdziwienie - zdumienie (język serbski)

\begin{tabular}{|l|l|r|}
\hline & $\begin{array}{l}\text { ухватити се / хватати се за главу } \\
\text { гртети (одмахивати) главом } \\
\text { влти се (завртело се) у глави некоме } \\
\text { као без главе (бити) } \\
\text { почешати се / чешати се по глави } \\
\text { не иде у главу некоме } \\
\text { не моћи ухватити чему ни репа ни главе }\end{array}$ & 7 \\
\hline OКО & $\begin{array}{l}\text { избечити / бечити (рогачити, расрогачити) очи } \\
\text { избељити / бељити очи } \\
\text { Ре веровати својим очима }\end{array}$ & 3 \\
\hline РВМЕ & слегнути / слегати (слећи) раменима & \\
\hline ЧЕЛО & не поверовати / не веровати својим ушима & 1 \\
\hline Razem & лупити се / лупати се (ударити се / ударати се) по челу & 1 \\
\hline
\end{tabular}

W grupie zaskoczenie - zdziwienie - zdumienie odnotowano 15 polskich oraz 13 serbskich związków frazeologicznych. Najwięcej frazeologizmów zawiera komponenty głowa i oko.

Zwroty typu:

pol. złapać się / łapać się (brać się, chwytać się, wziać się) za głowe

serb. ухватити се / хватати се за главу,

pol. podrapać się / drapać się po głowie

serb. почешати се / чешати се по глави

pochodzą z obserwacji ludzkich zachowań oraz gestów i odnoszą się do kogoś, kto jest czymś (daną sytuacją) zdziwiony, oszołomiony. Takie jednostki frazeologiczne odznaczają się znaczeniem symbolicznym. Podobnie frazeologizm:

pol. kręcić głowa

serb. вртети (одмахивати) главом

jest motywowany symbolicznie, co oznacza, że ktoś z powodu zaskoczenia rusza naprzemiennie głową raz w lewo, raz w prawo. Z kolei zwroty:

pol. kręci się komuś w głowie

serb. врти се (завртело се) у глави некоме

określają człowieka, który jest zaskoczony w wyniku silnie przeżytych emocji.

Jeden $\mathrm{z}$ frazeologizmów jest idiomatyczny dla języka serbskiego: моћи ухватити чему ни репа ни главе і оznacza zdziwienie w sytuacji, 
kiedy ktoś nie może zauważyć, w czym tkwi problem. Jest on motywowany metaforycznie.

W badaniu poświęconym analizie porównacznej trzech języków słowiańskich (polskiego, chorwackiego i rosyjskiego) Agnieszka Spagińska-Pruszak zaznacza, że w każdym z tych języków głowa zajmuje szczególne miejsce z powodu pełnionych funkcji, uniwersalności i wielkiego potencjału semantycznego. Głowa stanowi centrum pola semantycznego cech jakościowych intelektu wyrażonych za pośrednictwem somatyzmów. Frazeologizmy z tym komponentem wywodzą się z szerokiego semantycznego zakresu leksemu głowa oraz związanej z tym wyrazem głębokiej symboliki (Spagińska-Pruszak, 2005a, s. 85).

Kolejna grupa frazeologizmów to zwroty z komponentem oko:

pol. wybałuszyć (wytrzeszczyć) oczy

serb. избечити / бечити очи

ze znaczeniem 'otwierać oczy szeroko z wyrazem zdziwienia'. Obraz kogoś, kto jest zdumiony jakimś faktem, nie może uwierzyć w coś, co widzi czy też słyszy, przedstawiają wariantywne frazeologizmy, w których leksem oczy możemy zastąpić leksemem uszy:

pol. nie wierzyć własnym oczom

serb. не веровати својим очима

bądź

pol. nie wierzyć własnym uszom

serb. не веровати својим ушима.

Kolejne zwroty: zrobić / robić wielkie (duże) oczy // patrzeć na kogoś, na coś ostupiałymi oczyma // postawić / stawiać oczy w stup pokazują obraz człowieka, który jest czymś zdziwiony. Oczy są traktowane jako pojemnik na uczucia.

Zarówno zwroty polskie, jak i serbskie (pierwszy z członem nominalnym czoło, drugi z leksemem ramię: pol. puknać się w czoło // serb. луnumu ce no челу czy też pol. wzruszyć ramionami // serb. слегнути раменима) mają znaczenie dosłowne. W sensie literalnym są one motywowane ludzkim gestem. Pierwszy z nich oznacza podniesienie ręki w kierunku czoła i uderzenie się w nie, co oznacza zastanowienie się nad czymś, natomiast drugi - podniesienie i opuszczenie ramion, co jest oznaką zdziwienia. W przypadkach obu gestów mamy do czynienia z motywacją symboliczną. 


\section{Emocje negatywne}

Tabela 6. Złość - gniew - oburzenie - rozdrażnienie (język polski)

\begin{tabular}{|c|c|c|}
\hline GLOWA & • wylać / wylewać całą swą żółć na czyjąś głowę & 1 \\
\hline KREW & $\begin{array}{l}\text { krew się w kimś burzy } \\
\text { kipi (gotuje się, wre) krew w kimś } \\
\text { krew uderza (uderzyła) komuś do głowy } \\
\text { krew kogoś zalewa } \\
\text { psuć komuś krew (napsuć komuś krwi) } \\
\text { psuć sobie krew }\end{array}$ & 6 \\
\hline NERW & $\begin{array}{l}\text { stracić / tracić nerwy } \\
\text { iść (działać) komuś na nerwy } \\
\text { grać komuś na nerwach } \\
\text { popsuć / psuć (targać, rozstrajać) komuś (sobie) nerwy } \\
\text { puszczają (puściły) komuś nerwy }\end{array}$ & 5 \\
\hline NOGA & - wstać lewą nogą & 1 \\
\hline OKO & $\begin{array}{l}\text { błyskawice strzelają komuś z oczu } \\
\text { skoczyć / skakać komuś do oczu } \\
\text { być komuś cierniem (solą) w oku } \\
\text { rzucić się / rzucać się komuś do oczu }\end{array}$ & 4 \\
\hline PIERŚ & \ coś wzbiera (kipi) komuś w piersiach & 1 \\
\hline SERCE & $\begin{array}{l}\text { przepełnić żółcią serce } \\
\text { mieć złe serce dla kogoś }\end{array}$ & 2 \\
\hline SKÓRA & • wyskoczyć / wyskakiwać ze skóry & 1 \\
\hline UCHO & $\begin{array}{l}\text { poczerwienieć / czerwienić się (zaczerwienić się, (za)rumienić się) } \\
\text { po (same) uszy (powyżej uszu) }\end{array}$ & 1 \\
\hline USTA & $\checkmark \mathrm{z}$ pianą na ustach & 1 \\
\hline WARGI & • zaciskać / zacisnąć wargi & 1 \\
\hline WĄTROBA & $\begin{array}{l}\text { coś komuś pada (padło) na wątrobę } \\
\text { przewraca się (burzy się, rośnie) komuś (w kimś) wątroba } \\
\text { mieć coś na wątrobie } \\
\text { leży (zebrało się) coś komuś na wątrobie } \\
\text { popsuć / psuć komuś (sobie) wątrobę }\end{array}$ & 5 \\
\hline ZĄB & $\begin{array}{l}\text { zgrzytać zębami } \\
\text { wyszczerzyć / szczerzyć zęby } \\
\text { ostrzyć zęby na kogoś } \\
\text { mieć na kogoś ząb }\end{array}$ & 4 \\
\hline ŻÓŁĆ & $\begin{array}{l}\text { poruszyć komuś / w kimś żółć } \\
\text { wylać / wylewać całą swą żółć na kogoś } \\
\text { przepełnić żółcią serce } \\
\text { żółć kogoś zalewa } \\
\text { zionąć zółłcią }\end{array}$ & 5 \\
\hline \multicolumn{2}{|l|}{ Razem } & 38 \\
\hline
\end{tabular}


Tabela 7. Złość - gniew - oburzenie - rozdrażnienie (język serbski)

\begin{tabular}{|c|c|c|}
\hline БРАДА & ॰ угристи се за браду & 1 \\
\hline ВИЛИЦА & • стиснутих вилица & 1 \\
\hline ГЛАВА & • нагнати (натерати) крв у главу некоме & 1 \\
\hline $\begin{array}{l}\text { ЖИВАЦ / } \\
\text { НЕРВ }\end{array}$ & $\begin{array}{l}\text { изгубити / губити живце (нерве) } \\
\text { ићи (ударити) на живце (нерве) некоме } \\
\text { искидати / кидати (трошити) некоме (себи) живце (нерве) } \\
\text { живци (нерви) су некоме попустили }\end{array}$ & 4 \\
\hline ЖУЧ & $\begin{array}{l}\text { излити /изливати (просути / просипати) жуч на некога } \\
\text { искалити / искаљивати жуч на некога } \\
\text { † покрене се жуч некоме }\end{array}$ & 3 \\
\hline ЗУБ & $\begin{array}{l}\text { шкргутнути / шкргутати (шкрипати, шкрипнути) зубима } \\
\text { искезити / кезити зубе } \\
\text { оштрити (брусити) зубе на некога } \\
\text { ४ имати зуб на некога }\end{array}$ & 4 \\
\hline JETPA & • ићи на јетру некоме & 1 \\
\hline КОЖА & $\begin{array}{l}\text { искочити / искакати (изаћи, излетети) из коже } \\
\text { истерати из коже некога }\end{array}$ & 2 \\
\hline КРВ & $\begin{array}{l}\text { крв се узбунила (узбуркала) (у) некоме } \\
\text { кипи (кључа, ври) крв (у) некоме } \\
\text { удара (ударила је, навире, наврла је, појурила је, јурнула је) } \\
\text { крв у главу некоме } \\
\text { удара (ударила је, навире, наврла је, појурила је, јурнула је) } \\
\text { крв у лице некоме } \\
\text { удара (ударила је, навире, наврла је, појурила је, јурнула је) } \\
\text { крв у образе некоме } \\
\text { пада (пала је) крв на очи некоме }\end{array}$ & 6 \\
\hline ЛИЦЕ & $\begin{array}{l}\text { удара (ударила је, навире, наврла је, појурила је, јурнула је) } \\
\text { крв у лице некоме }\end{array}$ & 1 \\
\hline НОГА & • устати (дићи се) на леву ногу & 1 \\
\hline HOC & $\begin{array}{l}\text { дочекати с великим носом некога } \\
\text { радити (ићи, чинити) уз нос (под носом, пред носом) некоме } \\
\text { напети / напињати нос }\end{array}$ & 3 \\
\hline ОБРАЗ & $\begin{array}{l}\downarrow \text { ударила (пошла) је ватра у образ некоме } \\
\text { удара (бије) црвенило у образе некоме }\end{array}$ & 2 \\
\hline ОКО & $\begin{array}{l}\text { севнути / севати очима на некога, на нешто } \\
\text { бацити се / бацати се у очи некоме } \\
\text { гурнути / гурати прст у око некоме } \\
\text { скочити / скакати у очи некоме } \\
\text { с трн у оку бити некоме } \\
\end{array}$ & 5 \\
\hline ПРСТ & • гурнути / гурати прст у око некоме & 1 \\
\hline СРЦЕ & $\begin{array}{l}\text { искалити / искаљивати срце на некога } \\
\text { бити накрај срца } \\
\text { - имати зло срце на некога }\end{array}$ & 3 \\
\hline
\end{tabular}




\begin{tabular}{|l|l|r|}
\hline СТОМАК & стеже се у стомаку некоме & 1 \\
\hline УВО & поцрвенети до ушију & 1 \\
\hline УСТА & са пеном на устима & 1 \\
\hline УТРОБА & преврће се некоме утроба & 1 \\
\hline ЦРЕВО & искидати / кидати црева некоме & 1 \\
\hline ЧЕЛО & киша бије (удара, избија) из чела некоме & 1 \\
\hline Razem & & 45 \\
\hline
\end{tabular}

W wyekscerpowanym korpusie grupa złość - gniew - oburzenie - rozdrażnienie zawiera 38 polskich oraz 45 serbskich związków frazeologicznych.

Leksem krew najczęściej spośród nazw części ciała pojawia się we frazeologizmach. Krew jest siedliskiem życia i duszy. Krew i ciało w Nowym Testamencie (Mt 16,17; 1 Kor. 15,50) oznaczają kreaturalną naturę człowieka, w przeciwieństwie do boskiego życia duszy, do Duchów Bożych i samego Boga (Kopaliński, 1991, s. 169).

Za pomocą komponentu krew/кpв:

pol. krew się w kimś burzy

serb. крв се узбунила (у) некоме,

pol. kipi krew w kimś

serb. кипи крв (у) некоме

przedstawiony jest obraz negatywnych emocji. Negatywny obraz emocji przedstawiony jest także we frazeologizmach

pol. krew kogoś zalewa, psuć sobie krew

ze znaczeniem 'irytować się czymś' oraz w polskim zwrocie psuć komuś krew, który oznacza irytowanie drugiej osoby.

W języku polskim zwrot z dwoma komponentami krew i głowa: krew uderza (uderzyła) komuś do głowy ukazuje obraz człowieka, który się nagle zdenerwował. $\mathrm{W}$ języku serbskim mamy do czynienia z trzema wariantywnymi frazeologizmami (tab. 7), w których zamiast komponentu głowa używa się zamiennie komponentu лице (pol. twarz) oraz образ (pol.policzek) bez zmiany znaczenia frazeologicznego. Wszystkie zwroty są motywowane metaforycznie.

W języku serbskim z komponentami крв (pol. krew) і глава (pol.głowa) istnieje zwrot нагнати крв у главу некоме ze znaczeniem 'zezłościć kogoś', z kolei z komponentami крв (pol. krew) і око (pol. oko): пада (пала је) крв на 
очи некоме ze znaczeniem 'ktoś stracił nad sobą kontrolę ze złości'. Frazeologizmy te są uwarunkowane metaforycznie.

Człon nominalny nerw także jest produktywny w omawianej grupie. Nazwa części ciała w języku polskim - nerw zawiera w języku serbskim dwa odpowiedniki: живаи і нерв, przy сzym znaczenie frazeologizmu jest takie same. Sam komponent nerw symbolizuje negatywne emocje, określa stany gniewu, irytacji, napięcia, wzburzenia, rozdrażnienia (zob. Tyrpa, 2005). Związki frazeologiczne typu:

pol. stracić / tracić nerwy

serb. изгубити/губити живце (нерве)

czy tė

pol. puszczaja (puścity) komuś nerwy

serb. живии (нерви) су некоме попустили

przedstawiają obraz człowieka, który traci nad sobą panowanie, staje się nerwowy i wybucha gniewem. Kolejne dwa zwroty z tym samym komponentem:

pol. iść (działać) komuś na nerwy (grać komuś na nerwach)

serb. ићи (ударити) на живце (нерве) некоме;

pol. popsuć / psuć (targać, rozstrajać) komuś (sobie) nerwy

serb. искидати / кидати (трошити) некоме (себи) живце (нерве)

określają kogoś, kto się złości, denerwuje w wyniku negatywnego ludzkiego działania. Ten ostatni ma w języku serbskim wariantywny frazeologizm $\mathrm{z}$ komponentem uрево (pol.jelito): искидати / кидати ирева некоме. Wszystkie wymienione powyżej związki frazeologiczne z komponentem nerw są motywowane metaforycznie.

Duża liczba związków frazeologicznych występuje z komponentem żótć / жyu. Żółć - gorzki płyn magazynowany i wytwarzany w wątrobie - symbolizuje gorycz, zgorzknienie. Dlatego frazeologizmy z tym komponentem przywołują negatywne konotacje. W języku polskim zwroty typu:

poruszyć komuś / w kimś zółć,

wylać / wylewać cała swą żótć na kogoś (na czyjąś głowę),

żótć kogoś zalewa,

zionąć żółcią

odnoszą się do kogoś mocno zdenerwowanego, oburzonego, kogoś, kto wybucha gniewem w wyniku złośliwości innych osób. Podobnie przedstawia się obraz człowieka w języku serbskim: 
покрене се жуч некоме,

излити / изливати (просути / просипати) (сву своју) жуи на некога.

Negatywne emocje w człowieku ukazane są za pomocą frazeologizmu z komponentami żółć i serce, tj. przepełnić zółcią serce ze znaczeniem 'być złym, wściekłym'. $\mathrm{W}$ języku serbskim występują dwa wariantywne frazeologizmy. Uzewnętrzniają one uczucie gniewu, złości w stosunku do drugiego człowieka. Pierwszy z nich z komponentem жуч (pol. źółć): искалити / искаливати жуч на некога. Drugi występuje z komponentem срие (pol. sеrсе): искалити/искальивати срие на некога.

Serce jest siedliskiem nie tylko pozytywnych, lecz także negatywnych emocji. Jest ono symbolem m.in. oburzenia, rozdrażnienia, złości. Z komponentem serce / срuе występuje w języku polskim oraz serbskim frazeologizm:

pol. mieć złe serce dla kogoś

serb. имати зло срие на некога,

który w opozycji do zwrotu mieć złote serce odnosi się do kogoś, kto jest w stosunku do drugiej osoby nastawiony negatywnie.

Kolejne związki frazeologiczne mają w języku polskim jako człon nominalny rzeczownik wątroba i dwa leksemy o tym samym znaczeniu w języku serbskim: jempa i ympoбa. W polskim takimi zwrotami są m.in.

coś komuś pada na wątrobę,

przewraca się komuś (w kimś) wątroba, mieć coś na wątrobie,

psuć komuś (sobie) wątrobę.

Pokazują one obraz człowieka, którego coś gnębi, złości, irytuje. Podobne znaczenie frazeologiczne zostało zachowane we frazeologizmach w języku serbskim:

ићи на јетру некоме,

преврће се некоме утроба.

Wszystkie zwroty z tym komponentem przywołują negatywne konotacje, jako że wątroba symbolizuje negatywne stany emocjonalno-uczuciowe.

Związki frazeologiczne $\mathrm{z}$ komponentem oko / oкo także mają negatywne konotacje. Gdy blyskawice strzelaja komuś z oczu, oznacza to rzucanie gniewnych spojrzeń, podobnie jak w zwrocie serbskim севнути / севати очима на некога, на нешто. Zwroty te pochodzą ze skojarzenia zachowania rozgniewanego człowieka $z$ mogącym wywoływać negatywne emocje niebezpiecznym zjawiskiem atmosferycznym, jakim jest błyskawica. Frazeologizmy: 
pol. skoczyć komuś do oczu

serb. скочити у очи некоме;

pol. rzucić się komuś do oczu

serb. бащити се у очи некоме

pokazują obraz kogoś, kto atakuje drugiego człowieka w złości, fizycznie bądź werbalnie. Z kolei związek frazeologiczny być komuś cierniem (sola) woku, mający swój odpowiednik w języku serbskim: трн у оку бити некоме, pokazuje kogoś, kto jest przeszkodą dla drugiemu człowieka, zawadza mu, denerwuje go.

Zwrot występujący w języku serbskim z komponentami npcm (pol. palec) і око (pol. oko): гурнути / гурати прст у око некоме ze znaczeniem 'denerwować, drażnić kogoš' w znaczeniu metaforycznym odnosi się do nieprzyjaznych działań w stosunku do drugiego człowieka. W sensie literalnym zwrot ten może oznaczać dosłowne działanie - pol. wsadzić komuś palec w oko - i wówczas jest on motywowany symbolicznie.

Frazeologizm z komponentem zabb / sy6:

pol. zgrzytać zębami

serb. икргутнути / икргутати зубима

pokazuje obraz człowieka niezadowolonego oraz zdenerwowanego. $Z$ kolei zwrot:

pol. szczerzyć zęby

serb. кезити зубе

przedstawia obraz kogoś, kto uzewnętrznia swoje emocje poprzez złość, wściekłość. Podobny obraz człowieka zarysowuje się we frazeologizmach:

pol. ostrzyć zęby na kogoś

serb. очтрити зубе на некога,

pol. mieć na kogoś ząb

serb. имати зуб на некога,

które oznaczają negatywny stosunek do drugiej osoby.

Frazeologizm z komponentem skóra / кожа:

pol. wyskoczyć ze skóry

serb. искочити из коже

przedstawia obraz człowieka doznającego gwałtownego uczucia gniewu, tracącego nad sobą panowanie na skutek gwałtownej reakcji organizmu. 
W języku serbskim występuje związek frazeologiczny: истерати из коже некога. Oznacza on wyprowadzenie kogoś z równowagi.

Związek frazeologiczny z komponentem noga / нога:

pol. wstać lewa noga

serb. устати на леву ногу

ilustruje człowieka, który od samego rana jest w złym nastroju bez konkretnego powodu, dlatego jest zły i często nieprzyjemny w stosunku do swoich rozmówców. Na uformowanie znaczenia frazeologicznego wpłynął podział na prawą i lewą część ciała. Część prawa ciała ludzkiego jest uważana za pozytywną, podczas gdy część lewa przywołuje negatywne konotacje.

Związek frazeologiczny z komponentem ucho / yвo w zwrotach:

pol. poczerwienieć / czerwienić się po (same) uszy (powyżej uszu)

serb. почрвенети до ушију

ukazuje obraz człowieka, który ze złości mocno czerwieni się na twarzy. W języku serbskim występują dwa idiomatyczne związki frazeologiczne z komponentem oбраз (pol.policzek):

ударила је ватра у образ некоме,

удара ирвенило у образе некоме.

Obydwa frazeologizmy powstały na drodze mechanizmu metafory. Oznaczają człowieka odczuwającego złość, co przejawia się także zaczerwienieniem jego policzków, a nawet całej twarzy.

W języku polskim zwrot z leksemem wargi: zaciskać (zacisnąć) wargi, z kolei w języku serbskim z komponentem вилица (pol. szczęka): стиснутих вилица przedstawia obraz człowieka przeżywającego gniew. Wynika to z obserwacji, że zdenerwowany człowiek często nieświadomie zagryza wargi.

Wyrażenie z komponentem usta / ycma:

pol. $z$ piana na ustach

serb. са пеном на устима

odnosi się do kogoś, kto gwałtownie i nerwowo reaguje w danej sytuacji.

Z kolei serbski związek frazeologiczny z komponentem стомак (pol. brzuch): стеже се у стомаку некоме ze znaczeniem 'kogoś ogarnia złość, dopada atak gniewu' jest motywowany metaforycznie. Powstał na skutek ludzkich doświadczeń związanych z samoistną reakcją naszego organizmu - zdenerwowany człowiek może odczuwać silny ucisk w żołądku. 


\section{Wnioski}

Analizie semantyczno-kognitywnej poddano zebranych łącznie 145 związków frazeologicznych, z czego 70 to frazeologizmy polskie, a 75 - serbskie (tab. 8). Badane frazeologizmy umieszczono w trzech tematycznie wyodrębnionych grupach, które pokazują obraz człowieka i jego stany emocjonalno-uczuciowe. Najwięcej frazeologizmów przywołuje negatywne konotacje. Łączna liczba frazeologizmów wyrażających emocje negatywne wynosi 83, przy czym liczba ta jest większa w języku serbskim. Najmniejsza jest liczba związków frazeologicznych o znaczeniu neutralnym (łącznie 28 w dwóch badanych językach). Na podstawie przykładów z korpusu wynika, że związki frazeologiczne $z$ komponentem semantycznym wyrażające pozytywne i negatywne stany emocjonalno-uczuciowe przeważają nad frazeologizmami określającymi emocje neutralne.

Tabela 8. Podział frazeologizmów

\begin{tabular}{|l|c|c|c|}
\hline Emocje & Język polski & Język serbski & Ogółem \\
\hline Pozytywne & 17 & 17 & $\mathbf{3 4}$ \\
\hline Neutralne & 15 & 13 & $\mathbf{2 8}$ \\
\hline Negatywne & 38 & 45 & $\mathbf{8 3}$ \\
\hline Ogółem & 70 & 75 & $\mathbf{1 4 5}$ \\
\hline
\end{tabular}

Łączna liczba komponentów części ciała występujących w materiale języka polskiego wynosi 20, w języku serbskim - 28 .

Najliczniejsze nazwy części ciała, które wchodzą w skład związków frazeologicznych wyrażających emocje pozytywne, to w języku polskim: serce (7), głowa (3); w języku serbskim: сри,е (6), глава (3).

Co do emocji neutralnych, najwyższą frekwencję w dwóch analizowanych językach mają następujące nazwy części ciała - w języku polskim: głowa (6), oko (6); w języku serbskim: глава (7), око (3).

Z kolei najliczniejsze nazwy części ciała służące do wyrażania emocji negatywnych stanowią w języku polskim: krew (6), żółć (5), nerw (5), wątroba (5), oko (4), ząb (4); w serbskim: крв (6), око (5), живаи (4).

Zarówno części ciała wraz z symboliką, jaką niosą, jak i inne elementy wchodzące w skład struktury danego frazeologizmu, odegrały rolę przy próbie odczytania znaczeń niektórych związków frazeologicznych. Taka motywacja ma charakter wewnątrzjęzykowy (motywacja leksykalna). 
Przeprowadzone badanie wykazało występowanie zarówno podobieństw, jak i różnic między językiem polskim a serbskim w zakresie badanych jednostek frazeologicznych.

Występujące liczne podobieństwa w zakresie związków frazeologicznych między dwoma badanymi językami są m.in. wynikiem czerpania ze wspólnych źródeł kulturowych: słowiańskich, a także szerszych - europejskich. Wiele polskich i serbskich związków frazeologicznych kształtowało się w odległej przeszłości w sposób naturalny, na podstawie obserwacji ludzkich zachowań. Ponadto duży zasób słownictwa oraz struktur frazeologicznych wywodzi się z ludowej kultury Słowian. Duża liczba tego typu jednostek frazeologicznych jest motywowana znaczeniem symbolicznym. Taka motywacja ma szerszy charakter, być może wręcz globalny, i jest uwarunkowana czynnikami pozajęzykowymi, przede wszystkim społeczno-kulturowymi.

Pomimo wielu wspólnych związków frazeologicznych istnieją takie, które wywodzą się z odmiennych tradycji historycznych, kultury i literatury danego narodu, tym samym nigdy nie są one zrozumiałe i odczuwane w ten sam sposób przez użytkowników innego języka. Na takie zróżnicowanie frazeologizmów w języku polskim oraz serbskim miały wpływ różne losy historyczne obu narodów, po części odmienne tradycje kulturowe oraz mentalność, stąd w badanych jednostkach występują również związki idiomatyczne.

\section{Bibliografia}

Dobrowolska, J., \& Kawa, K. (2007). Słownik frazeologiczny. Wydawnictwo Europa.

Encyklopedia popularna PWN. (1985). Państwowe Wydawnictwo Naukowe.

Gerrod Parrott, W. (2001). Emotions in social psychology. Psychology Press.

Gojković, S. (2013). Somatizmi u nemačkoj i srpskoj frazeologiji (kontrastivna istraživanja). Filozofski fakultet u Novom Sadu.

Kopaliński, W. (1991). Słownik symboli. Wiedza Powszechna.

Lakoff, G., \& Johnson, M. (1988). Metafory w naszym życiu (T. Krzeszowski, Tłum.). Państwowy Instytut Wydawniczy.

Lewicki, A. M. (2003). Studia z teorii frazeologii. Oficyna Wydawnicza LEKSEM.

Lurker, M. (1989). Słownik obrazów i symboli biblijnych (K. Romaniuk, Tłum.). Pallottinum. Łosiak, W. (2007). Psychologia emocji. Wydawnictwa Akademickie i Profesjonalne.

Łuczyński, E., \& Maćkiewicz, J. (2009). Językoznawstwo ogólne. Wydawnictwo Uniwersytetu Gdańskiego. 
Matešić, J. (1982). Frazeološki rječnik hrvatskoga ili srpskog jezika. Školska knjiga.

Mušović, A. (2002). Somatske frazeološke jedinice za izražavanje emocija i njihova sintaksička funkcija (na materijalu ruskog i srpskog jezika). Filozofski fakultet.

Otašević, Đ. (2012). Frazeološki rečnik srpskog jezika. Prometej.

Pajdzińska, A. (1990). Jak mówimy o uczuciach? Poprzez analizę frazeologizmów do językowego obrazu świata. W J. Bartmiński (Red.), Językowy obraz świata (ss. 83-101). Uniwersytet Marii Curie-Skłodowskiej.

Skorupka, S. (1987). Słownik frazeologiczny języka polskiego (T. 1-2). Wiedza Powszechna.

Spagińska-Pruszak, A. (2005a). Intelekt we frazeologii polskiej, rosyjskiej i chorwackiej. Oficyna Wydawnicza LEKSEM.

Spagińska-Pruszak, A. (2005b). Język emocji. Oficyna Wydawnicza LEKSEM.

Tyrpa, A. (2005). Frazeologia somatyczna: Związki frazeologiczne o znaczeniach motywowanych cechami części ciała w gwarach polskich. Oficyna Wydawnicza LEKSEM.

Vujanić, M. (Red.). (2007). Rečnik srpskoga jezika. Matica srpska.

Živanović, Đ. (Red.). (1999). Poljsko-srpski rečnik (T. 1-2). Zavod za udžbenike i nastavna sredstva.

\section{A Comparative Cognitive-Semantic Analysis of Polish and Serbian Phraseological Units Which Are Related to Emotional-Affective States and Contain Components Referring to Parts of Human Body}

\section{Summary}

This article offers an analysis of Polish and Serbian phraseological units which are related to emotional-affective states and contain components referring to parts of human body. The cognitive-semantic analysis presented in the study considers 145 such units. The corpus is divided into three thematic groups, taking into account all three types of emotions: positive, neutral and negative. The article presents the meaning of phraseological units in focus and considers the impact of symbolism of given parts of the body on shaping it. The conclusion highlights the key similarities and differences between the Polish and Serbian phraseological units under discussion. 


\title{
Analiza kognitywno-semantyczna polskich oraz serbskich związków frazeologicznych z komponentem somatycznym określających stany emocjonalno-uczuciowe
}

\author{
Streszczenie
}

Celem artykułu jest prezentacja analizy związków frazeologicznych odnoszących się do stanów emocjonalno-uczuciowych z komponentem somatycznym w języku polskim oraz serbskim. Na podstawie korpusu, zawierającego 145 frazeologizmów, jednostki frazeologiczne zostały poddane semantyczno-kognitywnej analizie. Korpus został podzielony na trzy grupy tematyczne. Zaproponowana klasyfikacja uwzględniła wszystkie trzy typy emocji: pozytywne, negatywne oraz neutralne. Przedstawiono znaczenie badanych frazeologizmów oraz ukazano, w jakim stopniu symbolika danych części ciała wpłynęła na ukształtowanie znaczenia frazeologicznego. W końcowej części artykułu omówiono podobieństwa i różnice w zakresie polskich i serbskich związków frazeologicznych.

Keywords: phraseological units; somatisms; emotional-affective states; cognitive-semantic analysis

Słowa kluczowe: związki frazeologiczne; somatyzmy; stany emocjonalno-uczuciowe; analiza kognitywno-semantyczna

\footnotetext{
Vesna Jovanović-Mihaylov, University of Silesia in Katowice, Katowice, Poland

ORCID: https://orcid.org/0000-0003-0875-0001

Correspondence: vesna19@wp.pl

The preparation of this article was self-financed by the author.

Competing interests: The author has declared that she has no competing interests.
} 